\title{
Prevalence of nursing diagnosis of fluid volume excess in patients undergoing hemodialysis"
}

\author{
PREVALÊNCIA DO DIAGNÓSTICO DE ENFERMAGEM VOLUME DE LÍQUIDOS \\ EXCESSIVO EM PACIENTES SUBMETIDOS À HEMODIÁLISE
}

\section{PREVALENCIA DEL DIAGNÓSTICO DE ENFERMERÍA EXCESO DE VOLUMEN DE LÍQUIDOS EN PACIENTES SOMETIDOS A HEMODIÁLISIS}

\section{Maria Isabel da Conceição Dias Fernandes ${ }^{1}$, Ana Beatriz de Almeida Medeiros ${ }^{2}$, Beatriz Medeiros de Macedo ${ }^{3}$, Ana Beatriz Ferreira Vitorino ${ }^{3}$, Marcos Venícios de Oliveira Lopes ${ }^{4}$, Ana Luisa Brandão de Carvalho Lira ${ }^{5}$}

\begin{abstract}
Objective: To identify the prevalence of nursing diagnosis of fluid volume excess and their defining characteristics in hemodialysis patients and the association between them. Method: Cross-sectional study conducted in two steps. We interviewed 100 patients between the months of December 2012 and April 2013 in a teaching hospital and one hemodialysis clinic. The inference was performed by diagnostician nurses between July and September 2013. Results: The diagnostic studied was identified in $82 \%$ of patients. The characteristics that were statistically associated: bounding pulses, pulmonary congestion, jugular vein distention, edema, change in electrolytes, weight gain, intake greater than output and abnormal breath sounds. Among these, edema and weight gain had the highest chances for the development of this diagnostic. Conclusion: The analyzed diagnostic is prevalent in this population and eight characteristics presented significant association.
\end{abstract}

\section{DESCRIPTORS}

Prevalence

Nursing diagnosis

Renal dialysis

Signs and symptoms

Renal insufficiency, chronic

\section{RESUMO}

Objetivo: Identificar a prevalência do diagnóstico de enfermagem Volume de líquidos excessivo e de suas características definidoras em pacientes submetidos à hemodiálise e verificar a associação entre ambos. Método: Pesquisa transversal realizada em duas etapas. Foram entrevistados 100 pacientes, entre os meses de dezembro de 2012 e abril de 2013, em um hospital universitário e em uma clínica de hemodiálise. A inferência foi realizada por enfermeiros diagnosticadores, entre julho e setembro de 2013. Resultados: O diagnóstico estudado foi identificado em $82 \%$ dos pacientes. As características que apresentaram associação estatística foram: agitação, congestão pulmonar, distensão de jugular, edema, eletrólitos alterados, ganho de peso, ingestão maior que o débito e ruídos adventícios. Dentre estas, edema e ganho de peso apresentaram as maiores chances para o desenvolvimento desse diagnóstico. Conclusão: O diagnóstico analisado é prevalente nesta clientela e oito características apresentaram associação significante.

\author{
DESCRITORES \\ Prevalência \\ Diagnóstico de enfermagem \\ Diálise renal \\ Sinais e sintomas \\ Insuficiência renal crônica
}

\begin{abstract}
RESUMEN
Objetivo: Identificar la prevalencia del diagnóstico de enfermería Exceso de volumen de líquidos y sus características definitorias en pacientes sometidos a hemodiálisis y verificar la asociación entre ambos. Método: Estudio transversal, realizado en dos etapas. Se entrevistaron 100 pacientes, entre los meses de diciembre de 2012 y abril de 2013, de un hospital universitario y de una clínica de hemodiálisis. La inferencia diagnóstica fue realizada por enfermeros diagnosticadores, entre julio y septiembre de 2013. Resultados: El diagnóstico estudiado fue identificado en $82 \%$ de los pacientes. Las características que presentaron asociación estadística fueron: agitación, congestión pulmonar, distensión de la yugular, edema, electrolitos alterados, aumento de peso, ingesta mayor a las pérdidas y sonidos adventicios. Entre estos, el edema y el aumento de peso presentan mayor relación para la formulación del diagnóstico. Conclusión: Se concluye que el diagnóstico analizado es prevalente en esta población y que presentó asociación significativa con ocho características.
\end{abstract}

\author{
DESCRIPTORES \\ Prevalencia \\ Diagnóstico de enfermería \\ Diálisis renal \\ Signos y sintomas \\ Insuficiencia renal crónica
}

\footnotetext{
* Extracted from the dissertation "Acurácia dos indicadores clínicos do diagnóstico de enfermagem Volume de líquidos excessivo em pacientes submetidos à hemodiálise”, Federal University of Rio Grande do Norte, 2014. ${ }^{1}$ Master. Substitute Professor, Federal University of Rio Grande do Norte, Natal, RN, Brazil. bebel 6@hotmail.com ${ }^{2}$ Masters from Graduate Program in Nursing, Federal University of Rio Grande do Norte, Natal, RN, Brazil. ${ }^{3}$ Nursing undergraduate student, Federal University of Rio Grande do Norte, Natal, RN, Brazil. ${ }^{4}$ PhD. Associate Professor II, Federal University of Ceará, Fortaleza, CE, Brazil. ${ }^{5}$ PhD. Professor, Graduate Program in Nursing, Federal University of Rio Grande do Norte, Natal, RN, Brazil. 


\section{INTRODUCTION}

Chronic kidney disease (CKD) is a major cause of death and disability worldwide. In Brazil, it is considered a public health problem, as statistics show high mortality and morbidity, besides the high cost involved for doing the treatment $^{(1-2)}$. In 2012, the number of people on dialysis treatment was 97,586 , almost double compared to $2000^{(3)}$.

CKD is defined as progressive and irreversible loss of nephron functionality being classified into five stages, which are related to the glomerular filtration rate (GFR) and consequently the degree of failure of the patient. In the most advanced stage, stage five, called chronic renal failure (CRF) in the terminal stage, kidneys lose total control of homeostasis of the organism due to the large reduction of nephrons and the patient begins to presence intensely uremic symptoms ${ }^{(1,4)}$.

For the maintenance of life in these patients, renal replacement therapy is established, highlighting the peritoneal dialysis (PD) and hemodialysis (HD). Among the treatment options, HD is the most commonly performed ${ }^{(5)}$. Although this is quite efficient, it does not completely replace kidney function. Thus, regardless of fulfillment of clinical, food and water treatment, there is the accumulation of nitrogen excretions, fluid and electrolyte, which cause a number of signs and symptoms manifested in the various segments of the body ${ }^{(4)}$.

Among manifestations, fluid accumulation is a hallmark in renal patients on hemodialysis. This is corroborated by studies dealing with the profile of nursing diagnoses (ND) presented by these individuals, in which were identified high prevalence of ND of fluid volume excess ${ }^{(6-9)}$.

The ND of fluid volume excess, defined as increased isotonic fluid retention, was included in the NANDA International in 1982 and revised in 1996. It is organized in the nutrition domain and in the hydration class 5 , being composed of three related factors and 25 defining characteristics $^{(10)}$.

It is noteworthy that the occurrence of ND in question can cause serious complications in patients with CRF, such as acute pulmonary edema, circulatory overload with consequent decrease in the efficiency of the heart, leading to congestive heart failure and hypertension. The latter is the main risk factor for developing coronary artery disease, cerebrovascular disease and pulmonary congestion ${ }^{(2,4-5,11)}$.

Thus, if these complications are not treated quickly, they can further aggravate the health status of patients or even trigger death, being rapid accurate diagnosis of fluid volume excess by nurses, fundamental, in order to prevent or minimize the aforementioned complications. However, difficulties of nurses are apparent to distinguish between the major defining characteristics of the ND due to the presence of common characteristics to other ND and/or due to lack of knowledge about the specific diagnosis and its indicators.

Studies on the prevalence of nursing diagnoses and their indicators in specific populations are fundamental to clinical practice of nurses, in order to know the reality of the present nursing diagnoses in a given population and their common indicators contributes to the effective planning of interventions, providing adequate assistance and providing positive results. Furthermore, studies using the prevalence ratio help nurses to infer a more reliable diagnosis, with greater safety and speed, because it estimates the chances of an individual to be diagnosed in the presence of certain characteristic.

In this perspective, this study has questions, such as: What is the prevalence of nursing diagnosis of fluid volume excess and its clinical indicators in patients undergoing hemodialysis? Is there an association between this condition and its defining characteristics? Thus, the objective of this study was to identify the prevalence of nursing diagnosis of fluid volume excess and its defining characteristics in patients undergoing hemodialysis and to verify its association.

\section{METHOD}

Cross-sectional study, conducted in two steps. In the first step, the study was conducted in a teaching hospital and one hemodialysis clinic, both located in a city in the northeastern of Brazil.

The sample size was calculated according to the formula: $\mathrm{n}=\mathrm{Z}_{\alpha}^{2} \cdot \mathrm{S}_{\mathrm{e}} \cdot\left(1-\mathrm{S}_{\mathrm{e}}\right) / \mathrm{L}^{2} \cdot \mathrm{P}^{(12)}$. Considering the parameters: $95 \%$ confidence level, sensitivity conjectured with the $85 \%$ most important indicators, half of the length of the confidence interval constructed of $10 \%$ and a proportion of $50 \%$ of adults have the studied diagnosis. Applying the formula, we obtained a value of 98 individuals, we opted to have a total of 100 patients, who were selected by convenience, consecutively.

Inclusion criteria were: being a patient with chronic renal failure; perform hemodialysis; being present, at the time of data collection, in the first hour of hemodialysis, and patients aged 18 years or more. The exclusion criteria were: being in impaired physical and mental conditions that prevented data collection of all items of the instrument.

We used a questionnaire as an instrument of data collection, it was developed according to the defining characteristics present in the nursing diagnosis of fluid volume excess - NANDA International - supported by the literature, which contained the operational and conceptual definitions of each characteristic, in order to facilitate the instrument construction ${ }^{(13-14)}$. This instrument had opened and closed questions, divided into: sociodemographic and clinical data, data from general physical examination, and laboratory tests of segments. 
Data were collected during the months of December 2012 to April 2013, after approval by the Ethics Committee and pretest of the instrument, data collection was performed by the researcher and eight undergraduate students, who were properly trained. For the training, there was a qualification course, with a workload of 10 hours, in which we discussed the research topic, objectives, methodology, the nursing diagnosis of fluid volume excess and operational definitions of their defining characteristics, we also reviewed the clinical methods of physical examination.

We prioritize performing data collection in the first hour of hemodialysis aiming to the slightest change in the fluid volume, which has a great relationship with the time that the patient is on the machine. As the hemodialysis machine objective is to filter blood impurities and extract the amount of fluid volume excess, in the first hour, the amount of fluid removed is still small compared to the amount extracted at the last hour.

It is worth noting that some clinical indicators were collected in two different periods, not only at the time of the interview, but also in the preceding 48 hours, through patient chart and verbal reports of patients, bearing in mind that it aimed to identify changes in interdialytic period in which the patient does not perform hemodialysis. Thus, weight gain in a short period, oliguria, intake greater than output and changes in blood pressure were assessed in the range of 48 hours and not just occasionally, at the time of interview. However, we were not able to assess the characteristics change in mental status and change in respiratory pattern in two distinct periods; thus, we considered a change in these characteristics when the normal pattern was not found.

Thus, these characteristics as the others, although they were collected only at the time of interview, in a timely manner, they also aimed to investigate whether there was fluid volume excess in the interdialytic period, i.e. between one hemodialysis and another. Additionally, the characteristics change in electrolytes, decreased hemoglobin or hematocrit were collected through patient charts, laboratory tests from the month when data were collected were considered for this study.

In data organization, we built 100 spreadsheets in Microsoft Office Excel 2010, containing the list of defining characteristics of the diagnosis in the study, which were present, absent or did not apply to the individuals. The criterion does not apply was directed to the characteristics, which were not assessed, namely: increased pulmonary artery pressure and change in urinary density.

In the second step of the research, the diagnostic inference was performed by three diagnostician nurses, selected intentionally by the Research Group in Assistance Practices and Epidemiology in Health and Nursing of UFRN. For the selection of nurses, the following requirements were considered: published research on nursing diagnoses and/or clinical practice or teaching nephrology. The selected diagnosticians were submitted to a training and assessment in order to verify their ability of diagnostic inference for each patient.

For data collection at this step, the diagnosticians received an e-mail with 100 spreadsheets, containing the list of the 25 defining characteristics of the studied diagnosis, listed from data collected in the first step of the study. In each spreadsheet, the 25 characteristics were already marked as to the absence or presence. Thus, it was requested that the diagnosticians judged whether the nursing diagnosis was present or absent. In case of disagreement by the diagnosticians, the diagnosis was ruled by the majority. This data collection were conducted from July to September 2013.

For data analysis, we used descriptive and inferential statistics through IBM SPSS Statistic version 19.0 for Windows. In descriptive analysis, measures of central tendency and dispersion were used, and applied the Kolmogorov-Smirnov test to check the normality of the data. In addition to descriptive analysis of quantitative variables, mean and standard deviation were calculated. In inferential analysis, we used Pearson chi-square test and Fisher exact test for the analysis of association between the defining characteristics and diagnosis studied, considering $p<0.05$, being calculated the prevalence ratios.

This study was approved by the UFRN Research Ethics (Protocol No. 148428) and the Certificate of Presentation to Ethics Appreciation (No. 08696212.7.0000.5537). Patients and diagnosticians expressed their acceptance to participate in the study by signing a consent form.

\section{RESULTS}

Among study participants, 52\% were female, 50\% were brown, $57 \%$ lived with a partner, $84 \%$ were religious and $55 \%$ were retired. The average age was 51.16 years $( \pm 16.5)$, with a minimum of 19 years old and maximum of 86 years old.

The variables education and income presented asymmetric variation, indicating that half of the sample had up to six years of education and had family income of about twice the minimum wage. Regarding related morbidities, the main ones were hypertension (81\%) and diabetes (30\%).

Based on the data presented in Table 1, the nursing diagnosis of fluid volume excess was present in most of the sample $(82 \%)$, according to the judgment of diagnosticians. Among the defining characteristics frequent in more than $50 \%$ of the sample, we highlight: azotemia $(100 \%)$, decreased hematocrit $(96 \%)$, change in electrolytes $(88 \%)$, intake greater than output $(88 \%)$, restlessness and anxiety (85\%), edema (81\%), decreased hemoglobin (73\%), oliguria (63\%) and increased blood pressure (52\%).
Prevalence of nursing diagnosis of fluid volume excess in patients undergoing hemodialysis Fernandes MICD, Medeiros ABA, Macedo BM, Vitorino ABF Lopes MVO, Lira ALBC 
Table 1 - Prevalence of nursing diagnosis. Fluids volume excess and their defining characteristics in patients undergoing hemodialysis - Natal, RN, 2013

\begin{tabular}{|c|c|c|c|c|}
\hline Variables & Presence & $\%$ & Absence & $\%$ \\
\hline \multicolumn{5}{|l|}{ Nursing diagnosis } \\
\hline Fluid volume excess & 82 & 82.0 & 18 & 18.0 \\
\hline \multicolumn{5}{|l|}{ Defining characteristics } \\
\hline Azotemia & 100 & 100.0 & 00 & 0.0 \\
\hline Decreased hematocrit & 96 & 96.0 & 04 & 4.0 \\
\hline Change in electrolytes & 88 & 88.0 & 12 & 12.0 \\
\hline Intake greater than output & 88 & 88.0 & 12 & 12.0 \\
\hline Restlessness and anxiety & 85 & 85.0 & 15 & 15.0 \\
\hline Edema & 81 & 81.0 & 19 & 19.0 \\
\hline Decreased hemoglobin & 73 & 73.0 & 27 & 27.0 \\
\hline Oliguria & 63 & 63.0 & 37 & 37.0 \\
\hline Increased blood pressure & 52 & 52.0 & 48 & 48.0 \\
\hline Increased central venous pressure & 47 & 47.0 & 53 & 53.0 \\
\hline Hepatojugular positive reflux & 46 & 46.0 & 54 & 54.0 \\
\hline Bounding pulses & 44 & 44.0 & 56 & 56.0 \\
\hline Weight Gain & 42 & 42.0 & 58 & 58.0 \\
\hline Pulmonary congestion & 42 & 42.0 & 58 & 58.0 \\
\hline Abnormal breath sounds & 40 & 40.0 & 60 & 60.0 \\
\hline Jugular vein distention & 38 & 38.0 & 62 & 62.0 \\
\hline Orthopnea & 30 & 30.0 & 70 & 70.0 \\
\hline Dyspnoea & 25 & 25.0 & 75 & 75.0 \\
\hline Change in mental status & 19 & 19.0 & 81 & 81.0 \\
\hline Pleural effusion & 15 & 15.0 & 85 & 85.0 \\
\hline Anasarca & 08 & 8.0 & 92 & 92.0 \\
\hline Change in respiratory pattern & 04 & 4.0 & 96 & 96.0 \\
\hline Third heart sound S3 & 02 & 2.0 & 98 & 98.0 \\
\hline
\end{tabular}

In Table 2, we present the defining characteristics identified in the studied patients, which were associated with ND, as well as their prevalence ratios.

Consistent with Table 2, eight defining characteristics presented statistically significant association when related to the diagnosis of fluid volume excess $(p<0.05)$, as follows: bounding pulses, pulmonary congestion, jugular vein distension, edema, change in electrolytes, weight gain, intake greater than output and abnormal breath sounds.
Concerning the prevalence ratios of the characteristics mentioned above, the chances of patients with CRF on hemodialysis to develop nursing diagnosis of fluid volume excess in the presence of these characteristics were approximately three times for edema, $45 \%$ for weight gain, $38 \%$ for pulmonary congestion, $36 \%$ for abnormal breath sounds, $27 \%$ for bounding pulses and $21 \%$ for jugular vein distension when compared to patients without these characteristics.

Table 2 - Defining characteristics that were associated with the nursing diagnosis of fluid volume excess in patients undergoing hemodialysis - Natal, RN, 2013

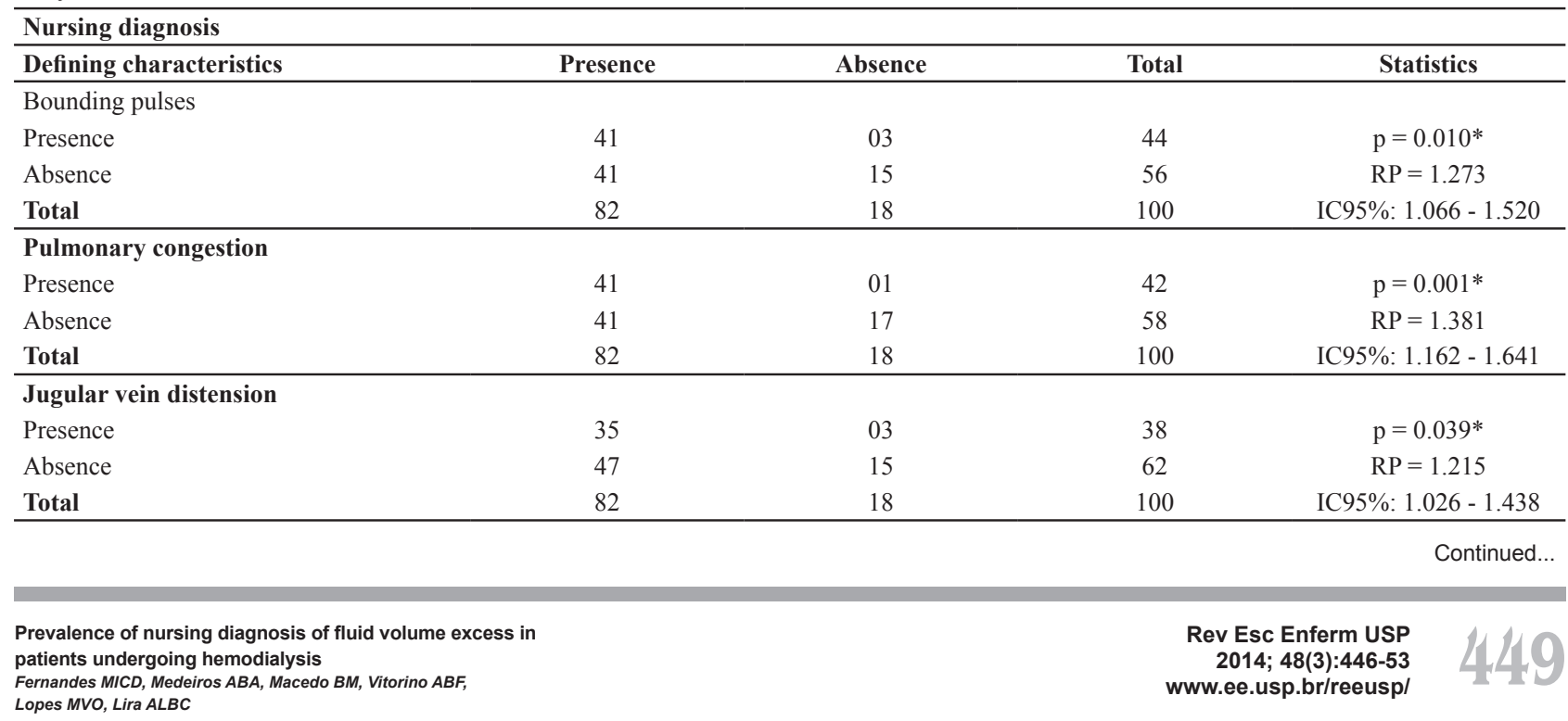


...Continuation

\begin{tabular}{|c|c|c|c|c|}
\hline \multicolumn{5}{|l|}{ Nursing diagnosis } \\
\hline Defining characteristics & Presence & Absence & Total & Statistics \\
\hline \multicolumn{5}{|l|}{ Edema } \\
\hline Presence & 76 & 05 & 81 & $\mathrm{p}=0.000^{* *}$ \\
\hline Absence & 06 & 13 & 19 & $\mathrm{RP}=2.971$ \\
\hline Total & 82 & 18 & 100 & IC95\%: $1.529-5.773$ \\
\hline \multicolumn{5}{|l|}{ Change in electrolytes } \\
\hline Presence & 75 & 13 & 88 & $\mathrm{p}=0.038^{* *}$ \\
\hline Absence & 07 & 05 & 12 & $\mathrm{RP}=1.461$ \\
\hline Total & 82 & 18 & 100 & IC95\%: $0.899-2.375$ \\
\hline \multicolumn{5}{|l|}{ Weight gain } \\
\hline Presence & 42 & 00 & 42 & $\mathrm{p}=0.000^{*}$ \\
\hline Absence & 40 & 18 & 58 & $\mathrm{RP}=1.450$ \\
\hline Total & 82 & 18 & 100 & IC95\%: $1.220-1.723$ \\
\hline \multicolumn{5}{|l|}{ Intake greater than output } \\
\hline Presence & 75 & 13 & 88 & $\mathrm{p}=0.038^{* *}$ \\
\hline Absence & 07 & 05 & 12 & $\mathrm{RP}=1.461$ \\
\hline Total & 82 & 18 & 100 & IC95\%: $0.899-2.375$ \\
\hline \multicolumn{5}{|l|}{ Abnormal breath sounds } \\
\hline Presence & 39 & 01 & 40 & $\mathrm{p}=0.001^{*}$ \\
\hline Absence & 43 & 17 & 60 & $\mathrm{RP}=1.360$ \\
\hline Total & 82 & 18 & 100 & IC95\%: $1.152-1.607$ \\
\hline
\end{tabular}

"Pearson chi-square test; " ${ }^{*}$ Fisher exact test; $\mathrm{p}<0,05 ; \mathrm{PR}=$ Prevalence ratio; $\mathrm{Cl}=$ Confidence interval.

Moreover, despite the statistically significant association between the characteristics intake greater than output and change in electrolytes and the ND studied, there is no way to establish the magnitude of the association, as the prevalence ratio was not statistically significant, due to the presence of the value one in confidence interval.

\section{DISCUSSION}

Regarding socioeconomic characterization, the present study identified prevalence of females, contrasting to the findings in the literature ${ }^{(3,15)}$. Regarding ethnicity, half of the patients were brown and the rest of the sample were white, black and yellow individuals. This result differs from some studies that show white people as the most prevalent in this condition ${ }^{(15-16)}$. However, another study claims that there is a higher risk for the development of CKD in black or brown people ${ }^{(17)}$.

Regarding marital status and religion, more than half of the sample reported they had a partner and also had some kind of religion, similar profile to one study ${ }^{(15)}$. In relation to age, according to the latest Census of Nephrology, the age group most affected by the CKD is between 19 and 65 years $^{(3)}$, which corroborates our research.

Regarding income, its origin would came, in most cases, from retirement, social security and pension, with only $10 \%$ coming from paid work. In this aspect, it is known that the majority of individuals with CKD undergoing hemodialysis need to abandon their work because of the limitations imposed by the disease and treatment; among these, we mention the physical problems, as well as the issue of the time taken to undergo hemodialysis, making it difficult for them to conduct work activities ${ }^{(18)}$.

Regarding education, the majority of the sample had about six years of study, corresponding to incomplete primary education. This result is in agreement with the literature, which claims that low education is a point to be highlighted, because it reflects the difficulty of assimilating the guidance provided on water treatment and food, which are very important for maintaining the health of these individuals ${ }^{(9,15)}$.

Regarding morbidities associated with CKD, the main ones were hypertension and diabetes, similar to the findings identified in the literature ${ }^{(3-2,16,19)}$. The systemic arterial hypertension ( $\mathrm{SAH}$ ) may be the cause, but also a consequence of the CKD; however, regardless of this, hypertension is responsible for the worsening of kidney disease ${ }^{(19)}$. Uncontrolled diabetes appears as another important predicting factor for CKD, thus chronic hyperglycemia is responsible for causing kidney injury ${ }^{(20)}$.

Regarding the prevalence of nursing diagnosis of fluid volume excess, most of the sample had this problem. The literature shows that patients with fluid accumulation is a frequent problem in hemodialysis units ${ }^{(4,6-9)}$. This diagnosis occurs, in the participants, due to the inability of their kidneys in performing their functions.

Although hemodialysis is efficient, it cannot completely replace kidney function, so that the fluid retention remains one of the major problems identified in this study, and associated with a number of indicators, such as edema, anasarca, pulmonary congestion, hypertension and heart failure ${ }^{(21)}$.
Prevalence of nursing diagnosis of fluid volume excess in patients undergoing hemodialysis Fernandes MICD, Medeiros ABA, Macedo BM, Vitorino ABF Lopes MVO, Lira ALBC 
According to the literature, there are no specific tests that can diagnose or exclude volume overload, but rather sets of the physical and laboratory examination are commonly used to diagnose hypervolemia ${ }^{(22)}$. Thus, this study provides some common characteristics and increase the chances of identifying fluid volume excess.

Thus, azotemia, identified throughout the investigated sample refers to the accumulation of urea and creatinine in the blood, which are responsible for causing effects in most parts of the body, the higher the accumulation, the higher the symptoms will be ${ }^{(4)}$. Corroborating the last finding, a study with similar people identified that the increase in rates of urea and creatinine was present in all participants ${ }^{(23)}$. It appears, therefore, that the presence of azotemia is independent of the presence or absence of excess fluid, because this characteristic is innate to the kidney problem, and always found in patients with any kidney deficit and not necessarily in the presence of excessive volume.

In this study, decreased hemoglobin or hematocrit were present in most patients, there were no significant association between them and the ND. Despite the lack of association, according to the literature, these characteristics are prevalent in this population, thus extensive association with renal failure due to production of erythropoietin, a hormone responsible for stimulating the production of red blood cells, which is absent, since it is produced by kidneys and these are no longer able to produce it ${ }^{(24)}$.

The changes in electrolytes characteristic was present in most patients and was statistically associated with the studied diagnosis. For its identification, we considered high dosages of sodium and potassium and/or decreased calcium. However, although the three electrolytes are considered to measure this characteristic, only the increase in serum sodium interferes significantly in water retention, because the accumulation of salt in the body raises indirectly the extracellular fluid volume ${ }^{(25)}$.

The defining characteristic intake greater than output also had high prevalence among the participants and it was associated with the diagnosis in question. In a study on the assessment of nutritional status in similar population, it was found that the fluid intake was high. Additionally, sodium intake was also above the recommended value, with average much higher, contributing to the increase in interdialytic weight gain, edema and increased blood pressure levels ${ }^{(26)}$.

In this study, the edema characteristic is highlighted, besides the high prevalence, it was statistically associated with the diagnosis and greater prevalence ratio, increasing by nearly three times the odds for those who had developed the analyzed diagnostic. The presence of this indicator in patients with CKD may be physiologically explained by the loss of ability to properly filter the electrolytes contained in blood. Thus, the sodium ion, responsible for the main volume of the liquid compartments of the organism, is causing expansion of extracellular volume through the positive sodium and water balance ${ }^{(4,25)}$.

Among the various types of edema, acute pulmonary edema or pulmonary congestion is a common cause of hospitalization in dialysis patients. Moreover, it is associated with interdialytic excess weight and the abusive use of salt and water ${ }^{(27)}$. In the study presented here, we identified an association between diagnosing pulmonary congestion and fluid volume excess. It is inferred that these findings are consistent with the high frequency of change in electrolytes and intake greater than output, which are causal factors in the occurrence of edema.

Thus, pulmonary congestion is a characteristic present in this population, the occurrence of Abnormal breath sounds would also be observed, since one of the major ways for congestion detection is by auscultation of breath sounds ${ }^{(14)}$. As congestion, rales were statistically associated with the diagnosis and considerable prevalence rate.

A study reported that abnormal findings, such as congestion in the pulmonary tree of such patients are frequently a result of bodily fluid overload in the interdialytic period, and greater weight gain during this period is associated with worsening of lung function ${ }^{(11)}$. Thus, the interdialytic weight gain appears to be an important variable to be considered in these patients, since their daily abrupt variation is related to the accumulation of liquids and hardly related to increased body mass ${ }^{(28)}$.

Although this characteristic has been identified in less than half of the sample, it is noteworthy that it was associated with the diagnosis studied, increasing by $45 \%$ the chances of patients developing such a diagnosis. A possible explanation for why it has not been identified with greater frequency may be related to the fact that it was adopted that the weight would be present only if there was an increase of two kilograms in the interdialytic period. However, it is known that weight changes in short periods are indicative of fluid retention ${ }^{(28)}$.

A study reveals that consumption of foods which are high in sodium, as well as excessive fluid intake and decrease in residual diuresis are directly related to interdialytic weight gain and increased blood pressure predialy$\mathrm{sis}^{(29)}$. In this sense, oliguria stands out as a contributor to fluid retention and characteristic increase in blood pressure is a result of the above factors.

Controlling blood pressure is related to the homeostasis of body fluid volume, which is determined by the balance between intake and output of fluid. This balance is pursued by many nervous, hormonal and kidneys controls, which regulate the excretion of salt and water ${ }^{(25)}$. However, as patients with CKD does not have this mechanism, they accumulate more than excrete, which inevitably causes an increase in blood pressure in the interdialytic period ${ }^{(4)}$. 
The characteristic jugular vein distention, despite having lower prevalence of $50 \%$, was statistically associated with the studied diagnosis and increased by $21 \%$ the chances for the occurrence of excessive volume. Most often, its occurrence was related to right ventricular failure, but all the conditions that generate superior vena cava pressure can cause it, such as the increase of circulating liquid ${ }^{(14)}$.

For psychological characteristics, restlessness and anxiety was present in most of the sample. One study claimed that this sign is closely related to pulmonary congestion and change in electrolytes, which presented, in this study, association with the diagnosis of fluid volume excess ${ }^{(28)}$.

In this perspective, bounding pulses, despite being present in fewer than $50 \%$ of the sample, was statistically associated with the diagnosis investigated, demonstrating $27 \%$ more chances for its occurrence. In renal patients, it can be derived from the change in electrolytes and the presence of excess fluid in the lungs, causing respiratory distress ${ }^{(28)}$. As pulmonary congestion and change in electrolytes were associated with the diagnosis, the occurrence of bounding pulses can be explained.

\section{CONCLUSION}

The studied diagnosis presented high frequency in the investigated sample. The defining characteristics found in more than half of the sample were: azotemia, decreased hematocrit, change in electrolytes, intake greater than

\section{REFERENCES}

1. Bastos MG, Bregman R, Kirsztajn GM. Doença renal crônica: frequente e grave, mas também prevenível e tratável. Rev Assoc Med Bras. 2010;56(2):248-53.

2. Jha V, Garcia-Garcia G, Iseki K, Li Z, Naicker S, Plattner B, et al. Chronic kidney disease: global dimension and perspectives. Lancet. 2013;382(9888):260-72.

3. Sociedade Brasileira de Nefrologia. Censo de diálise; 2012 [Internet]. São Paulo; 2012 [citado 2013 nov. 17]. Disponível em: http://www.sbn.org.br/pdf/publico2012.pdf

4. Riella MC. Princípios de nefrologia e distúrbios hidroeletrolíticos. 5a ed. Rio de Janeiro: Guanabara Koogan; 2010.

5. Pivato DR, Abreu IS. Principais causas de hospitalização de pacientes em hemodiálise no município de Guarapuava, Paraná, Brasil. Rev Gaúcha Enferm. 2010;31(3):515-20.

6. Souza EF, Martino MMF, Lopes MHBM. Diagnósticos de enfermagem em pacientes em tratamento hemodialítico utilizando o modelo teórico de Imogene King. Rev Esc Enferm USP. 2007;41(4):629-35. output, anxiety, edema, decreased hemoglobin, oliguria and increased blood pressure.

Among the characteristics that are statistically associated with the diagnosis, we highlight: pulmonary congestion, jugular vein distention, edema, weight gain, intake greater than output, change in electrolytes, bounding pulses and abnormal breath sounds. Of these, the one which presented higher prevalence ratios, increasing the chances for the development of the diagnostic studied, were: edema and weight gain.

Therefore, due to the high frequency of diagnosis of fluid volume excess, and highlighting the prevalent indicators, nurses involved in caring for such patients should primarily focus on control of blood volume and propose strategies for the therapeutic approach with a view to prevent the occurrence of such diagnosis and/or identify effective interventions.

We understand that this study contributed to the nursing care by identifying solid evidence on the relationship between the fluid volume excess and its characteristics. It is evident, though, the contribution of this study to strengthen nursing area, since we used the classification system of nursing diagnoses - NANDA International, a proper theoretical framework of nursing, fact that contributes to the improvement of communication among nurses.

As limitations, we highlight the fact that this study was conducted with a specific population, which has intrinsic peculiarities of their illness, for this reason, possible generalizations for people with other profiles should be restrained.
7. Costa AGS, Santos RMB, Vitor AF, Araujo TL. Diagnósticos de enfermagem de pacientes em tratamento de hemodiálise em hospital-escola. Rev Enferm UFPE On Line [Internet]. 2010 [citado 2013 nov. 17];4(3):1477-83. Disponível em: file://C:/ Documents\%20and\%20Settings/2509501/Meus\%20documentos/Downloads/1047-11619-1-PB.pdf

8. Dallé J, Lucena AF. Diagnósticos de enfermagem identificados em pacientes hospitalizados durante sessões de hemodiálise. Acta Paul Enferm. 2012;25(4):504-10.

9. Frazão CMFQ, Fernandes MICD, Nunes MGM, Sá JD, Lopes MVO, Lira ALBC. Componentes do modelo teórico de Roy em pacientes submetidos à hemodiálise. Rev Gaúcha Enferm. 2013;34(4):45-52.

10. Herdman TH. Diagnósticos de enfermagem da NANDA: definições e classificação - 2012/2014. 2ª ed. Porto Alegre: Artmed; 2013.
Prevalence of nursing diagnosis of fluid volume excess in patients undergoing hemodialysis Fernandes MICD, Medeiros ABA, Macedo BM, Vitorino ABF Lopes MVO, Lira ALBC 
11. Kovelis D, Pitta F, Probst VS, Peres CPA, Delfino VDA, Mocelin AJ, et al. Função pulmonar e força muscular respiratória em pacientes com doença renal crônica submetidos à hemodiálise. J Bras Pneumol. 2008;34(11):907-12.

12. Zhou XH, Obuchowski NA, Mcclish DK. Statistical methods in diagnostic medicine. New York: Wiley \& Sons; 2002.

13. Boery RNSO, Guimarões ECQCP, Barros ALBL. Definições operacionais das características definidoras do diagnóstico de enfermagem volume de líquidos excessivo. Acta Paul Enferm. 2005;18(2):197-202.

14. Bickley LS. Bates: propedêutica médica. 10a ed. Rio de Janeiro: Guanabara Koogan; 2010.

15. Vasconcelos CR, Dutra DA, Oliveira EM, Fernandes S. Perfil socioeconômico e clínico de um grupo de diabéticos em tratamento hemodialítico em Curitiba. Rev UNIANDRADE. 2013;14(2):183-200.

16. Ribeiro RCHM, Oliveira GASA, Ribeiro DF, Bertolin DC, Cesarino CB, Lima LCEQL, et al. Caracterização e etiologia da insuficiência renal crônica em unidade de nefrologia do interior do Estado de São Paulo. Acta Paul Enferm. 2008;21(n. esp):207-11.

17. Marques AB, Pereira DC, Ribeiro RCHM. Motivos e frequência de internação dos pacientes com IRC em tratamento hemodialítico. Arq Ciênc Saúde. 2005;12(2):67-72.

18. Reis CK, Guirardello EB, Campos CJG. O indivíduo renal crônico e as demandas de atenção. Rev Bras Enferm. 2008;61(3):336-41.

19. Bortolotto LA. Hipertensão arterial e insuficiência renal crônica. Rev Bras Hipertens. 2008;15(3):152-5.

20. Rubio LL, Fernández JS, Moreno IH. Complicaciones microvasculares: nefropatía diabética. Medicine. 2012;11(17):1003-10.
21. Kalantar-Zadeh K, Regidor DL, Kovesdy CP, Wyck DV, Bunnapradist S, Horwich TB, et al. Fluid retention is associated with cardiovascular mortality in chronic hemodialysis patients. Circulation. 2009;119(5):671-9.

22. Agarwal R, Andersen MJ, Pratt JH. On the importance of pedal edema in hemodialysis patients. Clin J Am Soc Nephrol. 2008;3(1):153-8.

23. Lata AGB, Albuquerque JG, Carvalho LASBP, Lira ALBC. Diagnósticos de enfermagem em adultos em tratamento de hemodiálise. Acta Paul Enferm. 2008;21 (n.esp):160-3.

24. Canziani MEF, Bastos MG, Bregman R, Pecoits Filho R, Tomiyama $C$, Draibe $S A$. Deficiência de ferro e anemia na doença renal crônica. J Bras Nefrol. 2006;28(2):86-90.

25. Guyton AC, Hall JE. Tratado de fisiologia médica. 11a ed. Rio de Janeiro: Elsevier; 2006.

26. Koehnlein EA, Yamada NA, Giannasi ACB. Avaliação do estado nutricional de pacientes em hemodiálise. Acta Sci Health. 2008;30(1):65-71.

27. Halle MP, Hertig A, Kengne AP, Ashuntantang G, Rondeau E, Ridel C. Acute pulmonary edema in chronic dialysis patients admitted into an intensive care unit. Nephrol Dial Transplant. 2012;27(2):603-7.

28. Boery RNSO, Barros ALBL. O diagnóstico de enfermagem Volume de líquidos excessivo. Salvador: Assembleia Legislativa do Estado da Bahia; 2008.

29. Nerbass FB, Morais JG, Santos RG, Krüger TS, Koene TT, Luz Filho HA. Fatores relacionados ao ganho de peso interdialítico em pacientes em hemodiálise. J Bras Nefrol 2011;33(3):300-5. 